\title{
Measuring Intramucosal pH in Very Low Birth Weight Infants
}

\author{
MORAG E. CAMPBELL AND KATE L. COSTELOE \\ Academic Department of Child Health, St. Bartholomew's and the Royal London School of Medicine and \\ Dentistry, Neonatal Unit, Homerton Hospital, London, United Kingdom E9 6SR
}

ABSTRACT

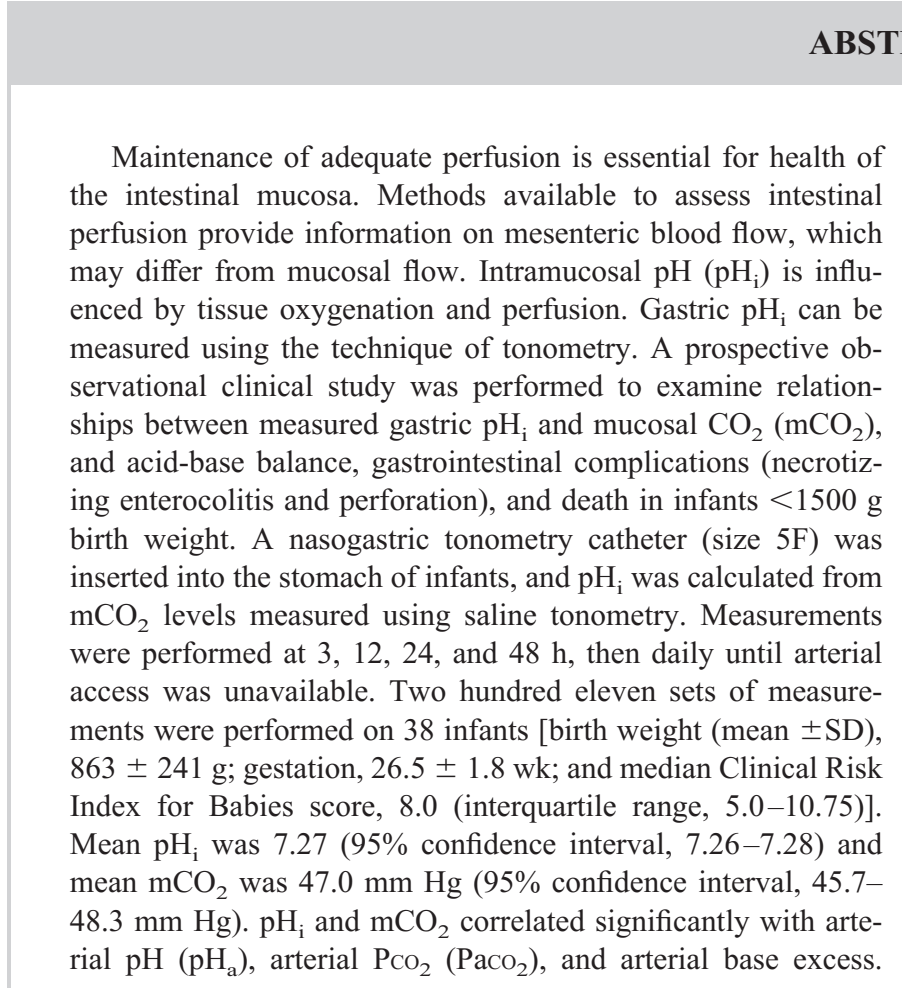

There were no significant relationships between $\mathrm{pH}_{\mathrm{a}}$ and $\mathrm{pH}$ gap $\left(\mathrm{pH}_{\mathrm{a}}-\mathrm{pH}_{\mathrm{i}}\right)$ or $\mathrm{CO}_{2}$ gap $\left(\mathrm{mCO}_{2}-\mathrm{PaCO}_{2}\right)$. Recurrent low $\mathrm{pH}_{\mathrm{i}}$ $\left(<7.2\right.$ on more than one occasion) and an $\mathrm{mCO}_{2} / \mathrm{PaCO}_{2}$ ratio of $\geq 1.29$ were significantly associated with an increase in gastrointestinal complications. There were no statistically significant associations with death. In conclusion, changes in $\mathrm{pH}$ gap and $\mathrm{CO}_{2}$ gap can occur without alteration in $\mathrm{pH}_{\mathrm{a}}$. Abnormalities in $\mathrm{pH}_{\mathrm{i}}$ might predict gastrointestinal complications in infants $<1500$ g. (Pediatr Res 50: 398-404, 2001)
$\mathbf{p H}_{\mathbf{i}}$, intramucosal $\mathrm{pH}$
Abbreviations
$\mathbf{p H}_{\mathbf{a}}$, arterial $\mathrm{pH}$
$\mathbf{m C O}_{2}$, mucosal $\mathrm{CO}_{2}$
GI, gastrointestinal
NEC, necrotizing enterocolitis
VLBW, very low birth weight
CI, confidence interval
$\mathbf{C V}$, coefficient of variability
SMA, superior mesenteric artery
CRIB, clinical risk index for babies
$\mathbf{P a C O}_{2}$, arterial $\mathrm{PCO}_{2}$

Mesenteric ischemia has been implicated in the pathogenesis of NEC $(1,2)$, which remains a significant cause of morbidity and mortality in VLBW infants (3). Hypoxia, either ante- or postnatally, may lead to redistribution of the cardiac output away from nonessential organs, including the intestine, to preserve oxygenation of essential organs. This may result in an imbalance of oxygen supply and demand in the gut, which may be further exacerbated by the introduction of enteral nutrition.

The ability to study intestinal perfusion at the mucosal level might benefit both the researcher attempting further to understand NEC and the clinician determining the optimal time to

Received June 22, 2000; accepted October 26, 2000.

Correspondence and reprint requests: Professor K.L. Costeloe, Academic Department of Child Health, St. Bartholomew's and the Royal London School of Medicine and Dentistry, Neonatal Unit, Homerton Hospital, London, United Kingdom E9 6SR; e-mail: K.L.Costeloe@qmw.ac.uk

Funded by a grant from the Joint Research Board of St. Bartholomew's Hospital (M.E.C.). introduce milk feeds $(4,5)$. Previously the only method available for the study of intestinal perfusion in the human newborn infant has been the study of blood flow velocity in the SMA and celiac artery using Doppler ultrasound. Although this may give insight into the resistance in the intestinal vascular bed, it cannot give information about the health of the intestinal mucosa.

Gastric $\mathrm{pH}_{\mathrm{i}}$, which will be influenced by oxygenation and perfusion, has been measured in animals and humans using the minimally invasive technique of gastric tonometry (6). The presence of large quantities of carbonic anhydrase in gastric mucosal cells enables rapid equilibration of $\mathrm{CO}_{2}$ from the submucosa to the gastric lumen. This technique is dependent on being able to measure $\mathrm{CO}_{2}$ at the mucosal surface $\left(\mathrm{mCO}_{2}\right)$ by equilibration with sterile saline in an intragastric gaspermeable Silastic balloon and substituting the result together with a concurrent estimate of arterial bicarbonate into the Henderson-Hasselbach equation. 
In animals this measurement of $\mathrm{pH}_{\mathrm{i}}$ has been shown to fall in response to gut ischemia induced by mechanical (7), physiologic $(8,9)$, and pharmacologic $(10)$ methods. In newborn piglets a relationship has been shown between $\mathrm{pH}_{\mathrm{i}}$ and SMA blood flow (10). These studies have shown that $\mathrm{pH}_{\mathrm{i}}$ may change in response to ischemia or regional hypoxia in the absence of changes in systemic acid-base balance or hemodynamics.

In adult critical care, sustained low gastric $\mathrm{pH}_{\mathrm{i}}$ has been associated with an increased risk of mortality and multiple organ dysfunction (11). Changes in mucosal blood flow both in the small intestine and the stomach measured using scanning laser Doppler have been correlated with $\mathrm{pH}_{\mathrm{i}}(12,13)$ measurements.

In limited data from the pediatric population, low values of $\mathrm{pH}_{\mathrm{i}}$ have been demonstrated to be predictive of mortality in septic shock (14) and independently to predict mortality in intensive care patients (15). In a population of children undergoing extracorporeal life support, the $\mathrm{CO}_{2}$ gap $\left(\mathrm{PaCO}_{2}-\mathrm{mCO}_{2}\right)$ had greater predictive power for mortality than $\mathrm{pH}_{\mathrm{i}}$, the predictive value for death with a $\mathrm{CO}_{2}$ gap of $>10 \mathrm{~mm} \mathrm{Hg}$ being $92 \%(16)$.

The objectives of the present study were to assess whether tonometry could be successfully performed in a population of VLBW infants; to establish ranges of values for $\mathrm{pH}_{\mathrm{i}}$ and $\mathrm{mCO}_{2}$ in this population in the early neonatal period, and to explore relationships between measured variables and systemic acidbase to quantify imbalances in $\mathrm{O}_{2}$ supply and demand at the mucosal level. In addition, pilot data were collected to examine for associations between the measured and calculated variables and the development of major GI complications and death.

\section{METHODS}

This was a prospective observational clinical study of $\mathrm{pH}_{\mathrm{i}}$ in infants $<1500 \mathrm{~g}$ birth weight in the early neonatal period.

Inclusion criteria were a birth weight $<1500 \mathrm{~g}$ and the presence of an indwelling arterial catheter. All catheters were placed for clinical purposes at the discretion of the responsible clinician. Infants with life-threatening congenital malformations or chromosomal anomalies were excluded. Recruitment only occurred when M.E.C. was available to perform measurements.

The study protocol was approved by the East London and City Health Authority Research Ethics Committee, and informed parental consent was obtained before study entry. Infants were recruited into the study as early as possible after delivery up to $24 \mathrm{~h}$ of age from the population admitted to the Neonatal Intensive Care Unit at the Homerton Hospital, London, during the period September 1998 to December 1999 inclusive. All intensive care management was conducted according to standard unit protocol. Decisions on the timing of commencement of enteral feed were made by the attending clinicians, who were not informed of $\mathrm{pH}_{\mathrm{i}}$ and $\mathrm{mCO}_{2}$ values.

After recruitment, measurements were taken at 3, 12, 24, and $48 \mathrm{~h}$ after study entry and thereafter on a daily basis until death or removal of the indwelling arterial line. Tonometry measurements were performed using a standard protocol. A single-use size $5 \mathrm{~F}$ dual-lumen nasogastric tonometry catheter (Tonometrics Inc., Worchester, MA, U.S.A.) was passed into the infant's stomach, and correct placement was confirmed at the time of routine abdominal radiography for arterial line position. At each sampling time the catheter balloon was instilled with 1.0 $\mathrm{mL}$ of sterile $0.9 \%$ saline and left to equilibrate for $45 \mathrm{~min}$. After equilibration, $0.3 \mathrm{~mL}$ of saline was withdrawn and discarded. The remaining $0.7-\mathrm{mL}$ sample was withdrawn anaerobically and immediately analyzed for $\mathrm{CO}_{2}$ content using a standard blood gas analyser (ABL Radiometer 520, Radiometer Medical A/S, DK-2700, Brønshøj, Denmark). The tonometry catheter used contained a gas-permeable Silastic balloon for which the correction factors for equilibration time for $\mathrm{CO}_{2}$ had been predetermined by the manufacturers. $\mathrm{mCO}_{2}$ levels were calculated using the correction factor for a $45-\mathrm{min}$ dwell time, $\mathrm{mCO}_{2}=$ saline $\mathrm{CO}_{2} \times 1.13$. Concurrent arterial blood samples of $0.2-\mathrm{mL}$ volume were drawn for measurement of blood gases and serum lactate (YSI 2300 Glucose/Lactate Analyzer, YSI, Inc., Yellow Springs, OH, U.S.A.). A single observer (M.E.C.) performed all measurements.

The nasogastric lumen of the catheters was left on free drainage and aspirated every $4-6 \mathrm{~h}$. The gastric contents were aspirated before performing all measurements. Infants were not routinely given $\mathrm{H}_{2}$ receptor antagonists.

Intramucosal $\mathrm{pH}\left(\mathrm{pH}_{\mathrm{i}}\right)$ was calculated using the HendersonHasselbalch equation: $\mathrm{pH}_{\mathrm{I}}=6.1+\log \left[\mathrm{HCO}_{3}\right] /\left(\mathrm{mCO}_{2} \times\right.$ 0.031 ). Where 6.1 is the negative logarithm of the dissociation coefficient of carbonic acid and 0.031 is the solubility of $\mathrm{CO}_{2}$ in plasma, $\mathrm{mCO}_{2}$ is the mucosal $\mathrm{CO}_{2}$ measured tonometrically and $\mathrm{HCO}_{3}$ is the bicarbonate concentration of a concurrent arterial blood gas. The following variables were calculated: $\mathrm{pH}$ gap $=\mathrm{pH}_{\mathrm{a}}-\mathrm{pH}_{\mathrm{i}}, \mathrm{CO}_{2}$ ratio $=\mathrm{mCO}_{2} / \mathrm{PaCO}_{2}$, and $\mathrm{CO}_{2}$ gap $=$ $\mathrm{mCO}_{2}-\mathrm{PaCO}_{2}$.

Repeatability of saline $\mathrm{CO}_{2}$ measurements was assessed by aspirating two samples simultaneously after removal of the catheter dead space. Samples were sealed and then immediately analyzed for $\mathrm{CO}_{2}$ content.

The following clinical data were collected:

Gestational age, birth weight, length, and cord gases as available.

Arterial blood gas and serum lactate were estimated concurrently with the tonometry saline $\mathrm{CO}_{2}$ measurements.

CRIB (severity of illness) scores, which has been shown to predict mortality in this birth weight group (17), were calculated for all subjects at $12 \mathrm{~h}$ of age. The total possible score of 22 is contributed to by birth weight ( $>1350 \mathrm{~g}, 0 ; 851-1350 \mathrm{~g}$, $1 ; 701-850 \mathrm{~g}, 4 ; \leq 700 \mathrm{~g}, 7)$, gestational age ( $>24 \mathrm{wk}, 0 ; \leq 24$ wk, 1), congenital malformations (none, 0 ; not acutely lifethreatening, 1; acutely life-threatening, 3), maximum base excess $(>-7.0 \mathrm{mM}, 0-7.0$ to $-9.9 \mathrm{mM}, 1 ;-10.0$ to -14.9 $\mathrm{mM}, 2$; $\leq-15.0 \mathrm{mM}, 3)$, minimum appropriate inspired $\mathrm{O}_{2}$ ( $\leq 40 \%, 0 ; 41-60 \%, 2 ; 91-100 \%, 3)$, and maximum appropriate inspired $\mathrm{O}_{2}(\leq 40 \%, 0 ; 41-80 \%, 1 ; 81-90 \%, 3 ; 91-100 \%$, 5).

Neonatal complications including overt signs of NEC.

Statistical analysis was performed using the Statistical Package for the Social Sciences (SPSS; Chicago, IL, U.S.A.). Statistical significance was set at the $95 \%$ level. Data are 
presented as mean $\pm \mathrm{SD}$ except when populations were not normally distributed, in which case data are presented as median (interquartile ranges).

Differences among groups were analyzed using ANOVA, $t$ test, and Mann-Whitney when normality tests failed. Differences in proportions between two groups were analyzed using Fisher's exact test and for more than two groups using $\chi^{2}$ for trend analysis. The $\mathrm{CV}$ was calculated using the following formula: $\mathrm{CV}(\%)=\mathrm{SD} /$ mean $\times 100$.

Correlation of mean values from individual subjects was used to assess the strength of the relationship between variables. Correlations were performed using Pearson's parametric correlation.

The clinical outcomes of death and major GI complications (NEC proven by the presence of intramural gas or perforation) were assessed in relation to the following tonometry-derived variables:

1. $\mathrm{pH}_{\mathrm{i}}$, with the subjects divided into three groups according to the lowest recorded $\mathrm{pH}_{\mathrm{i}}$ value (group $\mathrm{A}$ lowest $\mathrm{pH}_{\mathrm{I}} \geq 7.25$, group $\mathrm{B}$ lowest $\mathrm{pH}_{\mathrm{I}}<7.25$, and group $\mathrm{C}$ lowest $\mathrm{pH}_{\mathrm{I}}<7.2$ more than one occasions). These three groups were mutually exclusive.

2. $\mathrm{A} \mathrm{CO}_{2}$ gap $>10 \mathrm{~mm} \mathrm{Hg}$.

3. $\mathrm{A} \mathrm{CO}_{2}$ ratio $\geq 1.29$; this ratio represents the upper limit of a $\mathrm{CO}_{2}$ gap of $>10 \mathrm{~mm} \mathrm{Hg}$ within the normal $\mathrm{PaCO}_{2}$ range of $35-45 \mathrm{~mm} \mathrm{Hg}$.

\section{RESULTS}

During the study period, 38 infants were recruited (Table 1). Thirty-seven infants had umbilical arterial lines, and one infant had a radial arterial line inserted.

Gastric tonometry was successfully performed in all 38 infants; in one infant the tonometry catheter was found on radiography to be in the right main bronchus and was replaced. There were no complications encountered with tube dislodgement or balloon leakage. A total of 211 paired measurements of $\mathrm{pH}_{\mathrm{a}}$ and $\mathrm{pH}_{\mathrm{i}}$ were performed in the 38 subjects.

Repeatability of saline $\mathrm{CO}_{2}$ measurements under stable ventilatory and acid-base conditions were assessed on 26 occasions, the $\mathrm{CV}$ of $\mathrm{CO}_{2}$ was $5.6 \%(95 \% \mathrm{CI}, 4.3-7.1 \%)$.

Mean values for $\mathrm{pH}_{\mathrm{a}}, \mathrm{pH}_{\mathrm{i}}, \mathrm{PaCO}_{2}, \mathrm{mCO}_{2}, \mathrm{pH}$ gap, $\mathrm{CO}_{2}$ gap, and arterial base excess from all measurements $(n=211)$ are summarized in Table 2. The mean difference between $\mathrm{pH}_{\mathrm{a}}$ and

Table 1. Characteristics of study infants

\begin{tabular}{lc}
\hline \multicolumn{1}{c}{ Characteristic } & Study infants $(n=38)$ \\
\hline Birth weight $(\mathrm{g})$ & $862.7 \pm 241$ \\
Birth weight SD score & $0.35(-0.16$ to 0.1$)$ \\
Gestation age (wk) & $26.5 \pm 1.8$ \\
Sex & 24 male:14 female \\
CRIB score (severity of illness) & $8(5-10.75)$ \\
Cord pH $(n=28)$ & $7.29 \pm 0.1$ \\
Antenatal steroids & $35(92 \%)$ \\
Positive-pressure ventilation & $37(97 \%)$ \\
Exogenous surfactant & $37(97 \%)$ \\
Survival to discharge (\%) & $26(68.4 \%)$ \\
\hline
\end{tabular}

Data presented as mean \pm SD except for birth weight SD score and CRIB score, which are presented as median (interquartile range).
Table 2. Mean values of measured and calculated variables

\begin{tabular}{lc}
\hline \multicolumn{1}{c}{ Variable } & $n=211$ \\
\hline Arterial $\mathrm{pH}$ & $7.33(7.325-7.345)$ \\
Intramucosal $\mathrm{pH}$ & $7.27(7.26-7.28)$ \\
Arterial $\mathrm{CO}_{2}(\mathrm{~mm} \mathrm{Hg})$ & $41.61(40.35-42.9)$ \\
Mucosal $\mathrm{CO}_{2}(\mathrm{~mm} \mathrm{Hg})$ & $47.02(45.73-48.31)$ \\
$\mathrm{pH}$ gap $\left(\mathrm{pH}_{\mathrm{a}}-\mathrm{pH}_{\mathrm{i}}\right)$ & $0.064(0.058-0.070)$ \\
$\mathrm{CO}_{2}$ gap $\left(\mathrm{mCO}_{2}-\mathrm{PaCO}_{2}\right)$ & $5.41(4.79-6.03)$ \\
$\quad(\mathrm{mm} \mathrm{Hg})$ & \\
Arterial base excess & $-3.86(-4.21$ to -3.51$)$ \\
\hline
\end{tabular}

Data are presented as mean $(95 \% \mathrm{CI})$.

$\mathrm{pH}_{\mathrm{i}}$ was $0.064 \pm 0.046(95 \% \mathrm{CI}, 0.058-0.07 ; p<0.001)$ and between $\mathrm{PaCO}_{2}$ and $\mathrm{mCO}_{2}$ was $5.41 \pm 4.6 \mathrm{~mm} \mathrm{Hg}(95 \% \mathrm{CI}$, $4.79-6.03 \mathrm{~mm} \mathrm{Hg} ; p<0.001)$. Mean $\mathrm{pH}_{\mathrm{a}}$ and $\mathrm{pH}_{\mathrm{i}}$ at each time point measured during the first $5 \mathrm{~d}$ of life are illustrated in Figure 1.

Relationships between variables were examined using correlation analysis by calculating the mean values of each variable for each subject $(n=38)$ (Table 3 ).

$\mathrm{mCO}_{2}$ values correlated significantly with $\mathrm{PaCO}_{2}(r=0.9 ; p<$ 0.001; (Fig. 2) and $\mathrm{pH}_{\mathrm{a}}(r=-0.83 ; p<0.01)$. Similarly the calculated $\mathrm{pH}_{\mathrm{i}}$ values correlated significantly with $\mathrm{PaCO}_{2}(r=$ $-0.635 ; p<0.001)$ and $\mathrm{pH}_{\mathrm{a}}(r=0.88 ; p<0.001 ;$ Fig. 3$)$. There were no significant relationships between $\mathrm{pH}_{\mathrm{a}}$ and $\mathrm{pH}$ gap or $\mathrm{CO}_{2}$ gap. Arterial base excess correlated significantly with $\mathrm{mCO}_{2}(r=$ $-0.35 ; p=0.03), \mathrm{pH}_{\mathrm{i}}(r=0.79 ; p<0.0001$; Figs. 4 and 5$)$, and $\mathrm{pH}$ gap $(r=-0.21 ; p<0.001)$. There was no significant relationship between base excess and $\mathrm{CO}_{2}$ gap or $\mathrm{CO}_{2}$ ratio.

Lactate levels were high at birth; the mean value at $3 \mathrm{~h}$ was $1.44 \mathrm{mM}(95 \% \mathrm{CI}, 1.16-1.72 \mathrm{mM})$, then decreased significantly $(p<0.0001)$. There was no significant relationship demonstrated between lactate and $\mathrm{pH}_{\mathrm{i}}$ or $\mathrm{mCO}_{2}$.

Birth weight and gestation were not significantly different among groups $\mathrm{A}, \mathrm{B}$, and $\mathrm{C}$, although there was a nonsignificant trend toward lower gestation and birth weight in group $\mathrm{C}$ (Table 4). There was a significant trend toward an increased

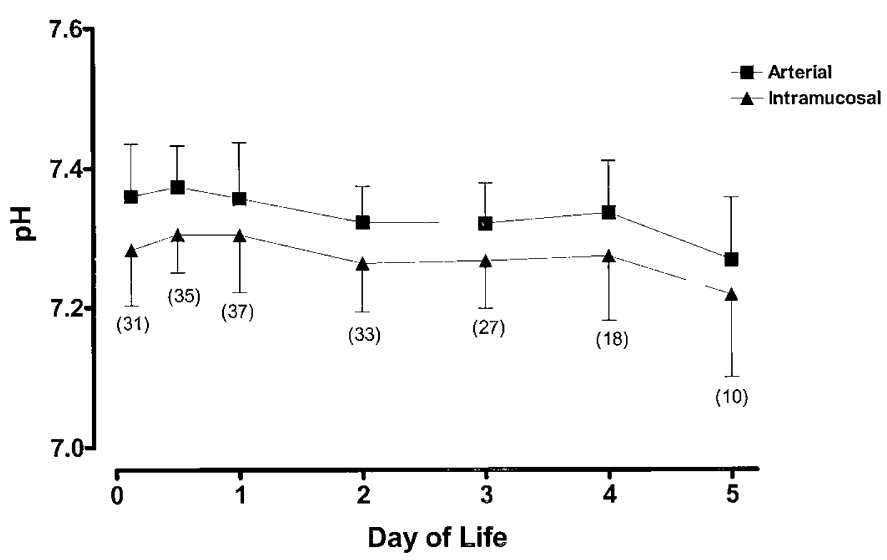

Figure 1. Changes in arterial and intramucosal $\mathrm{pH}$. Mean values $( \pm \mathrm{SD})$ for arterial and intramucosal $\mathrm{pH}$ at each time point during the first $5 \mathrm{~d}$ of life are presented; the number of subjects from which measurements were taken at each time point are presented in parentheses. $\mathrm{pH}_{\mathrm{i}}$ values are significantly lower than $\mathrm{pH}_{\mathrm{a}}$ values at each time point. 
Table 3. Mean values for measured and calculated variables in each individual subject

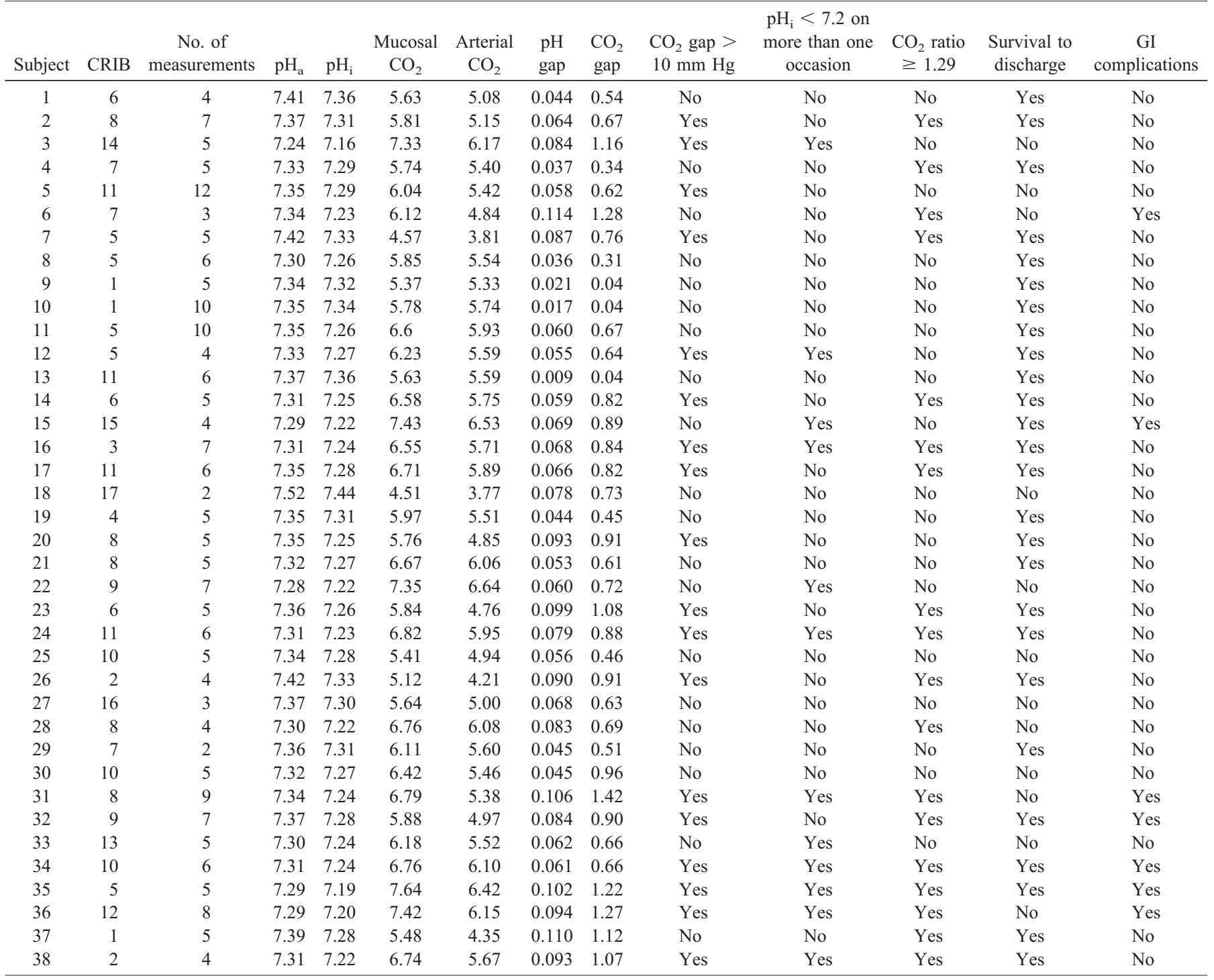

incidence of major GI complications in group C $(p=0.038, d f$ $\left.=1, \chi^{2}=4.5\right)$. There were no differences among groups in survival to discharge.

Eighteen infants had a $\mathrm{CO}_{2}$ gap of $>10 \mathrm{~mm} \mathrm{Hg}$. There was a trend toward an increased incidence of GI complications in these infants (5 of 18) in comparison to those with a gap of $<10 \mathrm{~mm} \mathrm{Hg}(1$ of 20$)$, but this did not achieve statistical significance $(p=0.08)$.

$\mathrm{A} \mathrm{CO}_{2}$ ratio of $\geq 1.29$ was present in 18 infants, six of whom developed major GI complications; there were no GI complications in the 20 infants with a ratio of $<1.29(p=0.007)$.

There were no statistically significant associations between low $\mathrm{pH}_{\mathrm{i}}$, a raised $\mathrm{CO}_{2}$ gap, or $\mathrm{CO}_{2}$ ratio and death.

\section{DISCUSSION}

There are few previous published data on gastric tonometry in the pediatric population, and there are none in preterm infants.

We have performed a total of 211 tonometry measurements in a population of $38 \mathrm{VLBW}$ infants without complication.
Measurement errors were minimized by having all measurements performed by a single operator. Saline $\mathrm{CO}_{2}$ levels were highly reproducible with a $\mathrm{CV}$ of $5.6 \%$. Problems relating to the instability of $\mathrm{CO}_{2}$ in saline were minimized by immediate analysis of saline samples. The underestimation of saline $\mathrm{CO}_{2}$ levels by standard blood gas analyzers (18) has been shown to be improved by the use of a phosphate-buffered solution (19). We elected to use a normal saline solution in the tonometry balloon as the blood gas analyzer used in this study (ABL 520) has been demonstrated to have the smallest bias in saline $\mathrm{CO}_{2}$ measurement (18). That no measurement of $\mathrm{pH}_{\mathrm{i}}$ was higher than concurrent $\mathrm{pH}_{\mathrm{a}}$ suggests that there was little $\mathrm{CO}_{2}$ diffusion before measurement in the blood gas analyzer. Errors may occur as a result of $\mathrm{CO}_{2}$ being generated in the stomach by the neutralization of gastric acid by duodenal bicarbonate. This effect may be minimized by administration of $\mathrm{H}_{2}$ receptor antagonists $(20,21)$ or by aspiration of gastric contents before performing tonometry measurements (22). In a population of critically ill patients, $\mathrm{pH}_{\mathrm{i}}$ values were not affected by the use of ranitidine (23). In this study $\mathrm{H}_{2}$ receptor antagonists were not 


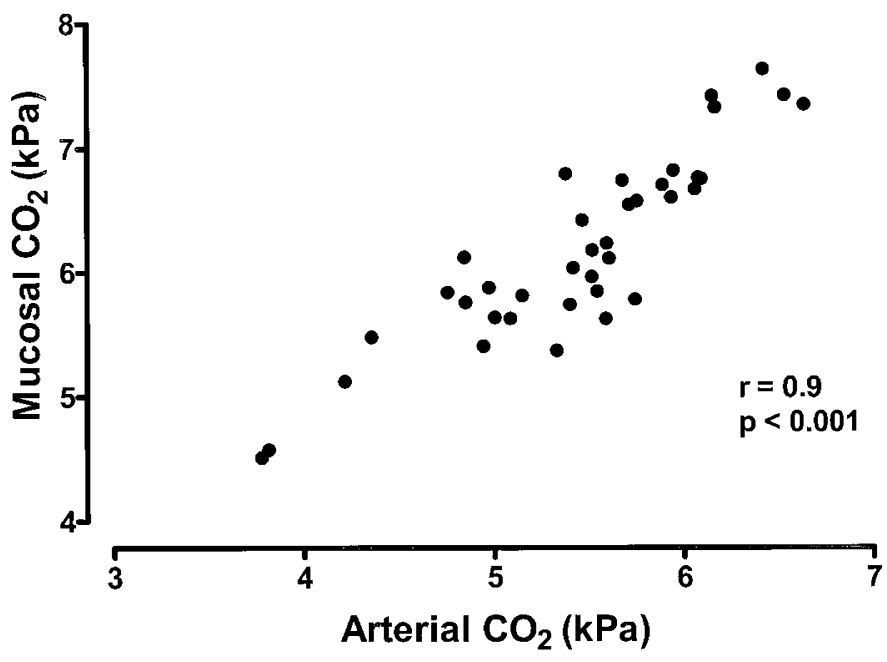

Figure 2. Correlation of arterial and mucosal $\mathrm{CO}_{2}$. Mean values for arterial and mucosal $\mathrm{CO}_{2}$ from all 38 subjects are plotted, demonstrating a highly significant correlation.

routinely administered; however, nasogastric tubes were kept on free drainage and aspirated before the tonometry measurements. The removal of the arterial line coincided with the commencement of enteral nutrition in all but one infant, who received $0.5 \mathrm{~mL} / 6 \mathrm{~h}$ expressed maternal milk for a $24-\mathrm{h}$ period while being studied. None of these infants were receiving $\mathrm{H}_{2}$ antagonists; premature infants demonstrate little unstimulated acid secretion, and acid-neutralization is unlikely to be a source of significant error. Theoretically tonometry measurements can be performed in infants being fed provided there is a sufficient time interval between feeds to allow for saline equilibration and all gastric contents are aspirated before study, but there are no published data in this population.

The time taken for $\mathrm{CO}_{2}$ equilibration using saline tonometry may mask acute changes occurring in $\mathrm{mCO}_{2}$ generation. This problem may be overcome using the technique of recirculating gas tonometry $(24,25)$, but currently suitable size $5 \mathrm{~F}$ catheters are not available.

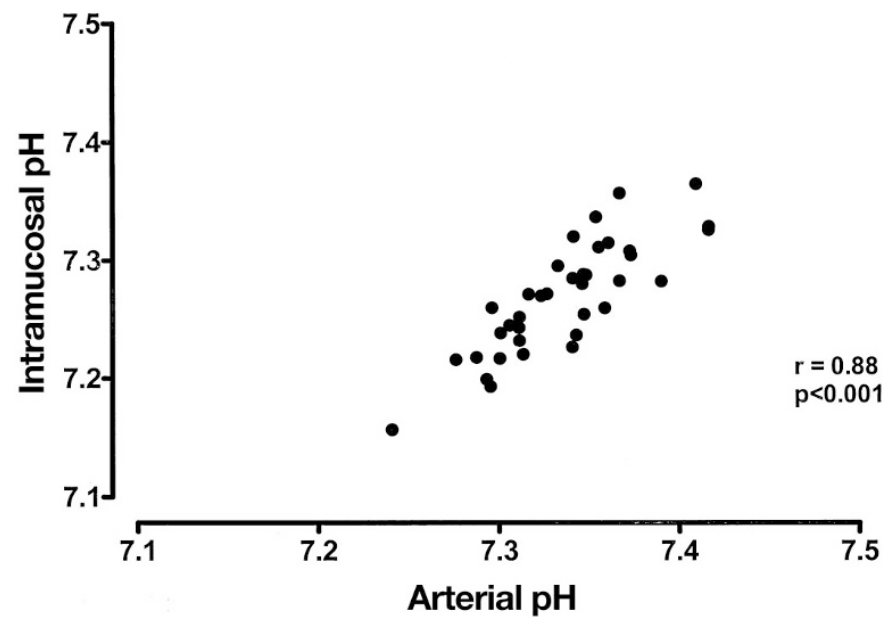

Figure 3. Correlation of arterial and intramucosal $\mathrm{pH}$. Mean values for arterial and intramucosal $\mathrm{pH}$ from all 38 subjects are plotted, demonstrating a high degree of correlation.

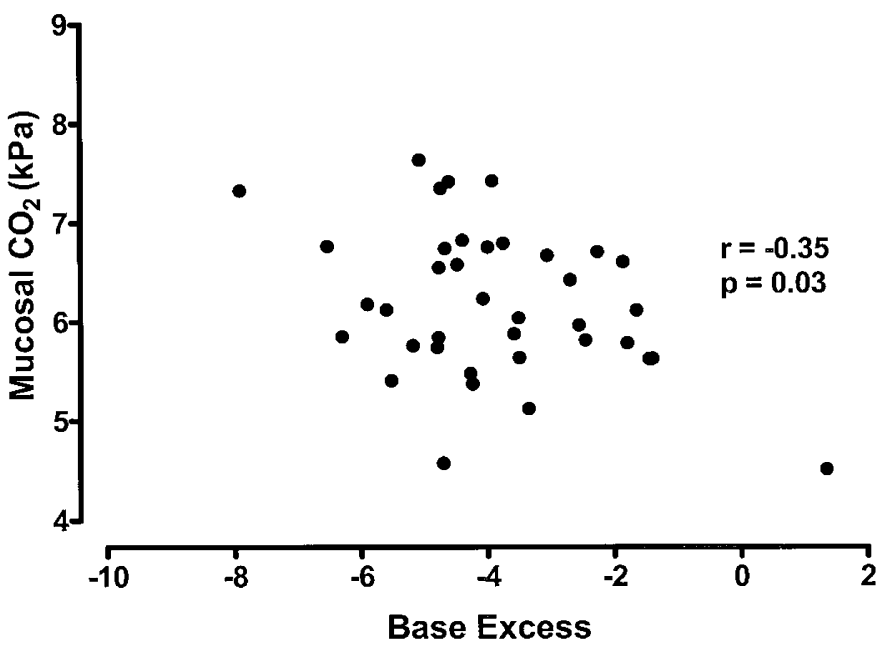

Figure 4. Correlation of arterial base excess and mucosal $\mathrm{CO}_{2}$. Mean values for both variables from all 38 subjects are plotted against each other. A significant negative correlation is demonstrated.

Using the total set of 211 measurements, we have established ranges for $\mathrm{pH}_{\mathrm{i}}, \mathrm{pH}$ gap, $\mathrm{mCO}_{2}$, and $\mathrm{CO}_{2}$ gap in this population of infants (Table 2). $\mathrm{pH}_{\mathrm{i}}$ values have previously been reported in healthy children undergoing general anesthesia $\left[\right.$ mean $\left.\mathrm{pH}_{\mathrm{i}}=7.35 \pm 0.06 ;(26)\right]$ and in a population of children with sepsis receiving intensive care $\left[\mathrm{pH}_{\mathrm{i}}=7.32 \pm\right.$ 0.18 in nonsurvivors and $7.48 \pm 0.07$ in survivors; (27)]. The mean value reported in the present study $\left(\mathrm{pH}_{\mathrm{i}}=7.27 \pm 0.078\right)$ is lower than in these pediatric populations.

This difference is likely to be contributed to by the tight control of ventilation achieved by clinical protocols in older children, by increased buffering capacity in comparison with this preterm population, and by the severity of illness in the study population as indicated by high CRIB scores (Table 1).

In previous studies relationships have been found between $\mathrm{pH}_{\mathrm{i}}$ and serum lactate $(28,29)$. In this study the high early lactate levels reflect the obstetric complications leading to preterm delivery. These elevated levels may not be attributable only to anaerobic glycolysis but also to direct effects of epinephrine on lactate metabolism in a stressed population (30,

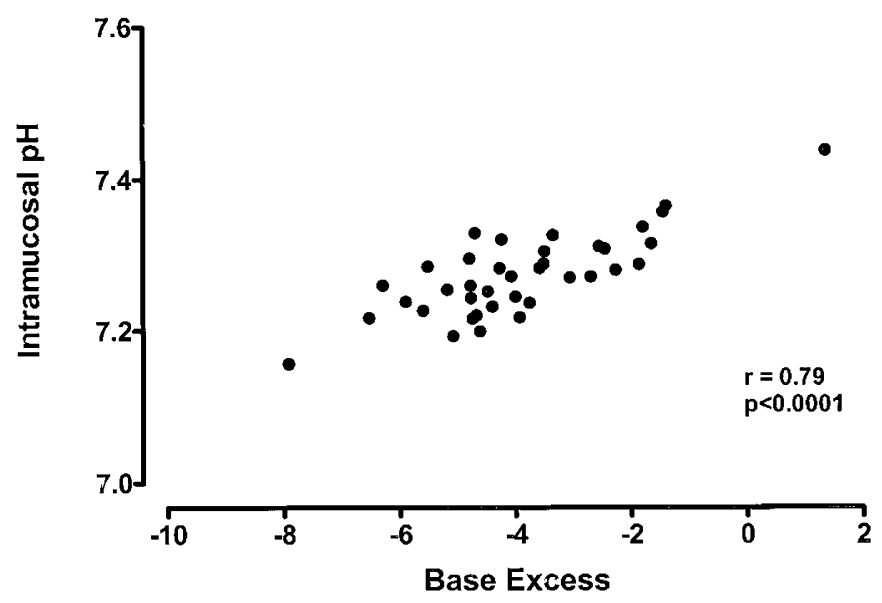

Figure 5. Correlation of arterial base excess and intramucosal $\mathrm{pH}$. Mean values for both variables from all 38 subjects are plotted against each other. A highly significant correlation is demonstrated. 
Table 4. Classification of study infants according to lowest recorded $\mathrm{pH}_{i}$ measurement*

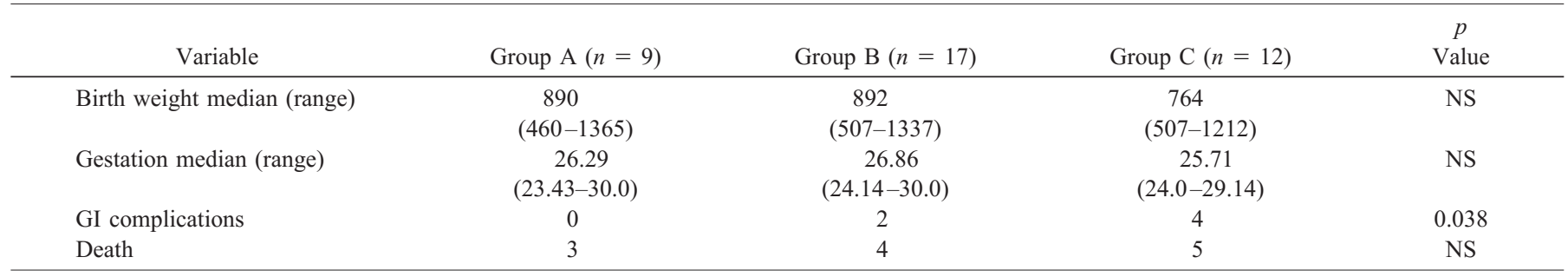

* Group $\mathrm{A}$, lowest $\mathrm{pH}_{\mathrm{i}} \geq 7.35$; group $\mathrm{B}$, lowest $\mathrm{pH}_{\mathrm{i}}<7.2$; group $\mathrm{C}$, lowest $\mathrm{pH}_{\mathrm{i}}<7.2$ on more than one occasion; groups $\mathrm{A}, \mathrm{B}$, and $\mathrm{C}$ are mutually exclusive.

31). The high lactate levels in the first $48 \mathrm{~h}$ may be masking an underlying relationship with $\mathrm{pH}_{\mathrm{i}}$. Unfortunately there are insufficient data beyond this time to explore associations satisfactorily.

The $\mathrm{pH}$ gap, $\mathrm{CO}_{2}$ gap, and $\mathrm{CO}_{2}$ ratio were all independent of $\mathrm{pH}_{\mathrm{a}}$. Calculated $\mathrm{pH}$ gap and $\mathrm{CO}_{2}$ gap provide an indication of the adequacy of oxygenation at the mucosal level, widening gaps reflecting progressive imbalance in oxygen delivery and mucosal cell metabolism. The absence of significant relationships between these variables and systemic acid-base status demonstrate the ability of the technique of gastric tonometry to detect problems at the mucosal level that might not be suspected from routine measurements of arterial blood gases.

The potential clinical usefulness of tonometry in VLBW infants has been confirmed by recurrent low values of $\mathrm{pH}_{\mathrm{i}}$ and a $\mathrm{CO}_{2}$ ratio of $\geq 1.29$ both being associated with major GI complications. The association between low $\mathrm{pH}_{\mathrm{i}}$ and major GI complications has been previously reported in two term infants with hypoplastic left heart syndrome, who developed low levels of $\mathrm{pH}_{\mathrm{i}}$ before the onset of NEC (32).

Changes in arterial $\mathrm{CO}_{2}$ levels affect the small-caliber resistance vessels producing constriction and dilation in response to systemic hypocapnia or hypercapnia (33). In experimental animals, Guzman et al. (34) have shown that systemic hypocapnia results in ileal mucosal and serosal hypoperfusion. $\mathrm{PaCO}_{2}$ levels in the study population varied in response to episodes of acute respiratory deterioration. To adjust for these effects, we calculated $\mathrm{CO}_{2}$ ratio $\left(\mathrm{mCO}_{2} / \mathrm{PaCO}_{2}\right)$, in a neonatal model. $\mathrm{CO}_{2}$ ratio has been shown to increase with decreasing intestinal blood flow (10). A ratio of $\geq 1.29$ was significantly associated with increased incidence of major GI complications $(p=0.007)$, with a sensitivity of $1.0(95 \% \mathrm{CI}, 0.54-1.0)$ and specificity of $0.625(95 \% \mathrm{CI}, 0.44-0.79)$ for identifying infants who had GI complications.

In contrast to reported adult $(11,29)$ and pediatric data $(14-16,27)$ from critically ill patients, we have not found statistically significant associations between death and recurrent low $\mathrm{pH}_{\mathrm{i}}, \mathrm{CO}_{2}$ ratio of $\geq 1.29$, and $\mathrm{CO}_{2}$ gap of $>10 \mathrm{~mm} \mathrm{Hg}$ in this heterogeneous group of VLBW infants. A larger study would be required to confirm associations between these measurements and death in the newborn. If size $5 \mathrm{~F}$ catheters for recirculating gas tonometry become available, the sensitivity and specificity of tonometry to predict adverse neonatal outcomes may increase.

Tonometry provides a simple, reproducible way of assessing mucosal metabolic status. This study provides data that suggest that $\mathrm{pH}_{\mathrm{i}}$ is independently predictive of major GI complications in the neonatal intensive care unit setting. The extent of its usefulness in the research and clinical fields on its own or in combination with other techniques such as Doppler ultrasound needs further evaluation.

\section{REFERENCES}

1. Nowicki PT, Nankeveris CA 1994 The role of the circulation in the pathogenesis of necrotizing enterocolitis. Clin Perinatol 219:219-234

2. Coombs RC, Morgan ME, Durbin GM, Booth IW, McNeish AS 1992 Abnormal gut blood flow velocities in neonates at risk of necrotizing enterocolitis. J Pediatr Gastroenterol Nutr 15:13-19

3. Uauy RD, Fanaroff AA, Korones SB, Phillips EA, Phillips JB, Wright LL 1991 Necrotizing enterocolitis in very low birthweight infants: biodemographic and clinical correlates. J Pediatr 119:630-638

4. Schanler RJ, Shulman RJ, Lau C, Smith EO, Heitkemper MM 1999 Feeding strategies for premature infants: randomized trial of gastrointestinal priming and tube-feeding method. Pediatrics 103:434-439

5. LaGamma EF, Browne LE 1994 Feeding practices for infants weighing $<1500 \mathrm{~g}$ at birth and the pathogenesis of necrotizing enterocolitis. Clin Perinatol 21:271-306

6. Antonsson JB, Boyle III CC, Kruithoff KL, Wang H, Sacristan E, Rothschild HR, Fink MP 1990 Validation of tonometric measurement of gut intramural pH during endotoxemia and mesenteric occlusion in pigs. Am J Physiol 259:G519-G523

7. Boros M, Kaszaki J, Ordogh B, Nagy S 1994 Intramucosal pH changes following complete segmental small intestinal ischaemia, as compared with the effects of superior mesenteric artery occlusion. Eur Surg Res 26:76-86

8. Hartmann M, Montgomery A, Jonsson K, Haglund U 1991 Tissue oxygenation in hemorrhagic shock measured as transcutaneous oxygen tension, subcutaneous oxygen tension, and gastrointestinal intramucosal $\mathrm{pH}$ in pigs. Crit Care Med 19:205-210

9. Montgomery A, Hartmann M, Jonsson K, Haglund U 1989 Intramucosal pH measurement with tonometers for detecting gastrointestinal ischemia in porcine hemorrhagic shock. Circ Shock 29:319-327

10. Campbell ME, VanAerde JE, Cheung PY, Mayes D 1999 Tonometry to estimate intestinal perfusion in the newborn piglet. Arch Dis Child 81:105-109

11. Maynard N, Bihari D, Beale R, Smithies M, Baldock G, Mason R, McColl I 1993 Assessment of splanchnic oxygenation by gastric tonometry in patients with acute circulatory failure. JAMA 270:1203-1210

12. Boyle NH, Pearce A, Hunter D, Owen WJ, Mason RC 1998 Scanning laser Doppler flowmetry and intraluminal recirculating gas tonometry in the assessment of gastric and jejunal perfusion during oesophageal resection. Br J Surg 85:1407-1411

13. Elizalde JI, Hernandez C, Llach J, Monton C, Bordas JM, Pique JM, Torres A 1998 Gastric intramucosal acidosis in mechanically ventilated patients: role of mucosal blood flow. Crit Care Med 26:827-832

14. Hatherhill M, Tibby SM, Evans R, Murdoch IA 1998 Gastric tonometry in septic shock. Arch Dis Child 78:155-158

15. Casado-Flores J, Mora E, Perez-Corral F, Martinez-Azagra A, Garcia-Teresa MA, Ruiz-Lopez MJ 1998 Prognostic value of gastric intramucosal pH in critically ill children. Crit Care Med 26:1123-1127

16. Duke T, Butt W, South M, Shann F 1997 The $\mathrm{DCO}_{2}$ measured by gastric tonometry predicts survival in children receiving extracorporeal life support: comparison with other hemodynamic and biochemical information. Chest 111:174-179

17. The International Neonatal Network 1993 The CRIB (clinical risk index for babies) score: a tool for assessing initial neonatal risk and for comparing performance of neonatal intensive care units. Lancet 342:193-198

18. Takala J, Parviainen I, Siloaho M, Ruokonen E, Hamalainen E 1994 Saline $\mathrm{pCO}_{2}$ is an important source of error in the assessment of gastric intramucosal $\mathrm{pH}$. Crit Care Med 22:1877-1879

19. Knichwitz G, Kuhmann M, Brodner G, Mertes N, Goeters C, Brussel T 1996 Gastric tonometry: precision and reliability are improved by a phosphate buffered solution. Crit Care Med 24:512-516

20. Kolkman JJ, Groenveld AB, Meuwissen SG 1994 Effect of ranitidine on basal and bicarbonate enhanced intragastric pCO2: a tonometric study. Gut 35:737-741

21. Heard SO, Helsmoortel CM, Kent JC, Shahnarian A, Fink MP 1991 Gastric tonometry in healthy volunteers: effects of ranitidine on calculated intramural $\mathrm{pH}$. Crit Care Med 19:271-274

22. Parviainen I, Vaisanen O, Ruokonen E, Takala J 1996 Effect of nasogastric suction and ranitidine on the calculated gastric intramucosal $\mathrm{pH}$. Intensive Care Med 22:319323 
23. Calvet X, Baigorri F, Duarte M, Saura P, Royo C, Joseph D, Mas A, Artigas A 1998 Effect of ranitidine on gastric intramucosal $\mathrm{pH}$ in critically ill patients. Intensive Care Med 24:12-17

24. Guzman JA, Kruse JA 1996 Development and validation of a technique for continuous monitoring of gastric intramucosal pH. Am J Respir Crit Care Med 153:694-700

25. Heinonen PO, Jousela IT, Blomqvist KA, Olkkola KT, Takkunen OS 1997 Validation of air tonometric measurement of gastric regional concentration of $\mathrm{CO}_{2}$ in critically ill septic patients. Intensive Care Med 23:524-529

26. Reinoso-Barbero F, Calvo C, Lopez-Herce J, Bueno M, Garcia S 1998 Reference values of gastric intramucosal $\mathrm{pH}$ in children. Paed Anaesthesia 8:135-138

27. Krafte-Jacobs B, Carver J, Wilkinson JD 1995 Comparison of gastric intramucosal pH and standard perfusional measurements in pediatric septic shock. Chest 108:220-225

28. Duke TD, Butt W, South M 1997 Predictors of mortality and multiple organ failure in children with sepsis. Intensive Care Med 23:684-692
29. Friedman G, Berlot G, Kahn RJ, Vincent JL 1995 Combined measurements of blood lactate concentrations and gastric intramucosal $\mathrm{pH}$ in patients with severe sepsis. Crit Care Med 23:1184-1193

30. Reverte M, Garcia-Barrada MJ, Moratinos J 1991 Change in plasma glucose and lactate evoked by alpha and beta-2-adrenoreceptor stimulation in conscious fasted rabbits. Fund Clin Pharmacol 5:663-676

31. James JH, Luchette FA, McCarter FD, Fischer JE 1999 Lactate is an unreliable indicator of tissue hypoxia in injury or sepsis. Lancet 354:505-508

32. Hatherhill M, Tibby SM, Denver L, Marsh MJ, Murdoch I 1998 Early detection of necrotizing enterocolitis by gastrointestinal tonometry. Acta Paediatr 87:344-345

33. Cullen J, Eger EI 1974 Cardiovascular effects of carbon dioxide in man. Anaesthesiology 41:345-349

34. Guzman JA, Kruse JA 1999 Splanchnic hemodynamics and gut mucosal-arterial $\mathrm{PCO}_{2}$ gradient during systemic hypocapnia. J Appl Physiol 87:1102-1106 